Roper, Jonathan (ed.): Dictionaries as Sources of Folklore Data. Folklore Fellows Communications 32I. Helsinki: Academia Scientiarum Fennica, 2O2O, 246 p.

\title{
Dictionaries as Sources of Folklore Data
}

David HOPKIN

Hertford College, Oxford

The origin of folklore studies as a distinct branch of knowledge was intimately connected to the development of philology - the study of the history of languages and literatures - in the first half of the nineteenth century. Many folklore pioneers were philologists, equally involved in editing ancient manuscripts and tracing the relationship of oral traditions to vernacular literatures. They were also, as the editor of this volume points out, lexicographers. Obvious examples include the brothers Grimm who considered the Deutsches Wörterbuch their greatest undertaking. They commenced work on it in I838, the first volume appeared in I854, and the last (of thirty-two) in I96I, nearly a hundred years after the brothers' death, having been completed by successive teams of scholars. It remains the most important dictionary of the German language. The influence of the brothers' folkloric activities is clearly on display in the early volumes: for instance, according to the folklorist Wolfgang Mieder, they provide one of the largest collections of German proverbs. ${ }^{.}$If anything the folkloric contribution looms even larger in Vladimir Dahl's Explanatory Dictionary of the Living Great Russian Language (I863-66), the most important Russian dictionary of the nineteenth century, which contains at least 30,000 proverbs in addition to other folkloric content. ${ }^{2}$

The collection under review does not contain chapters on the Grimms or Dahl; nor are there chapters on Elias Lönnrot, compiler of the first Finnish-Swedish dictionary (I866-I880) as well as of the Kalevala, nor on Niccolò Tommaseo, collector of folksongs and co-editor of the leading nineteenth-century dictionary of Italian (I86I-I874), nor on Antoni Maria Alcover, progenitor of the Diccionari català-valencià-balear (I930-I962), who drew extensively on his collection of Mallorcan folktales and songs. (However, some of the lexicographers covered in this volume were in close contact with Jacob Grimm, and influenced by him, including Vuk Karadžić, the editor of the first dictionary of the Serb language, Srpski rječnik in I8I8.) These absences only go to show how fruitful it might be to bring together lexicography and folklore. The focus in this collection is less on languages with a long history of written literature than on those minority, regional or dialectal languages which necessarily rely more on oral tradition for evidence of word use. Hence there are chapters on several varieties of Greek, Halbertsma's Frisian dictionary Lexicon Frisicum (I872), Feilberg's Dictionary of Jutlandic Folk Speech (I886-I9I4), Sampson's The Dialect of the Gypsies of Wales (I926), and dictionaries of Newfoundland English, Caribbean English as well as

I Wolfgang Mieder: 'Findet, so werdet ihr suchen!” Die Brüder und das Sprichwort. Bern: Peter Lang, I986.

2 Ilya VINITSKY: "Lord of the Words: Vladimir Dahl's Explanatory Dictionary of the Living Great-Russian Language as a National Epic". In Sarah OGILVIE and Gabriella SAFRAN (eds): The Whole World in a Book: Dictionaries in the Nineteenth Century. Oxford: Oxford University Press, $202 \mathrm{O}$. 
of the English regions. In addition to Vuk's Serb dictionary, more comprehensive and 'national' dictionaries are represented by Father Patrick Dinneen's An Irish-English Dictionary (I9O4), something of a monument in Irish letters, with the priest himself making an off-stage appearance in James Joyce's Ulysses. The majority of chapters concern Europe but as the editor notes, geography is not a substantial limitation to this kind of study.

After the editor's introduction, the chapters are arranged in three sections. The first is more historical, looking at the processes through which dictionaries were compiled. Here we find Tim Tangherlini's chapter on Feilberg which looks in detail at Feilberg's word collecting practices, including his sometimes testy relations with other Jutland folklorists, but which also serves as a condensed history of lexicography in Denmark as a whole. The second section offers some surveys of the folklore contained in dictionaries, while the last section focuses on the methodological issues that arise from folklorists' contributions to, and interrogation of, dictionaries. For instance, does the folklorist-lexicographer have a responsibility to correct popular errors and delusions, as Lise Winer argues in her chapter on the Dictionary of the English/Creole of Trinidad \& Tobago (2009)? This section also contains Philip Hiscock's reflections on using Kirwin's and Widdowson's Dictionary of Newfoundland English (I982, though now online) as a tool for teaching folklore students.

The intellectual relationship between philology and folklore is briefly considered in the editor's introduction. According to Jacob Grimm, all words, however abstract, derive from sensate experience. Language encoded and relayed experience from one generation to another, but each language differed because each people's experiences also differed, for example in their interactions with the natural world. Grimm further argued, in a Romantic reaction to the Enlightenment's universality of reason, that a people's ability to develop was limited by their language's potential for expression, which was itself historically conditioned. Language, like folklore, was a shared and collective inheritance, which grew and changed; it offered innumerable opportunities for selfexpression, but they were not limitless. Language put bounds on what could be thought and said, what could be imagined even, and so, as with folklore, one was always working within a tradition.

For those influenced by this Grimmian legacy, lexicography is necessarily an identity-making activity, as language standardization reifies ethnic divisions into nations - or would-be nations - whose immutable and distinct character is both produced and bequeathed by language. But even at the sub-national level, the very existence of a dictionary is a claim to cultural distinction which might, in turn, generate calls for some kind of political recognition. Dictionaries are inherently boundary-forming as they obligate choices about what should be included, what excluded, and what words can be legitimately claimed by one region, one people, one state, rather than another. Hence the criticisms levelled at a predecessor of the Dictionary of Newfoundland English which included definitions for such terms as Balderdash, Dank and Hustings which were to all intents and purposes identical to their use in wider Canadian English and, for that matter, the entire Englishspeaking world. When does a word belong to Newfoundland and nowhere else, and what follows from that attribution? The political ramifications of lexicography are not foregrounded in this volume, but they are acknowledged. 
Some of Jacob Grimm's ideas find an echo in Jeremy Harte's rich chapter on Welsh Romani, a distinct dialect of the language spoken by Gypsies across Europe, and maintained in Wales by a handful of families for two hundred years; it is now more or less defunct. We owe our knowledge of it thanks to the fortuitous encounter between the Wood family and the linguist and librarian of Liverpool University, John Sampson. One of the Woods' several words for ghost was meriklo, which derives from the word for necklace, a gift for a loved one, and therefore by extension a word for the loved one him or herself, and then again by extension someone who returns to haunt the family. Thus we move from sensate experience to imagined reality, as Grimm anticipated. Harte observes that "the Romani thoughtworld", as presented in the dictionary entries, "is disconcertingly magical: within a single entry, fiddlers and fishermen suddenly jostle with dragons, giants and hell-hounds". Language shaped culture in this distinct tradition, even though the Woods' speech also contained multiple borrowings from their Welsh- and English-speaking neighbours. But on the whole philosophical considerations of the relationship between language and thought, with their problematic essentialist implications, are left to one side in this collection. The intention here is to consider dictionaries as assemblies of folkloric information, and how these might be mined.

Dictionaries, by their nature, favour shorter verbal traditions, material often overlooked by collectors as beneath notice. Proverbs are the most ubiquitous, having been a regular feature of dictionaries from the sixteenth century onwards, but the various chapters here also highlight jokes, puns, tongue-twisters, charms, curses, prayers, prognostications, toasts, greetings, farewells, vows, blessings, threats, riddles, naming and nicknaming practices, and numerous other "small genres". But dictionaries also contain evidence of customs, when they describe how an object was used. In Vuk's Serb dictionary, for example, the head-word zapis [writing] includes information about the magical use of writing in amulets and cures. The ethnographic content of dictionaries can be quite substantial, as in the early Greek dialect glossaries considered in Haralampos Passalis' chapter, with their entries on folk festivals such as the Cappodocian feast of Vartouvaria. Dictionary entries offer much evidence of belief, sometimes served up in proverbial form such as the Frisian saying De kranke ligt to bedde un de fege sit d'r feur [meaning that the visitor to the sickbed was in greater danger of dying than its occupant]. Even after belief had passed away, words and phrases have the power to summon up older worldviews: for instance, in Frisian babies are not "received" but are "fetched", suggesting that they come from somewhere else. And, of course, supernatural creatures also require definitions, including the douen, jumbie, La Diablesse, Mama Glo, Papa Bois, Phantom, and soucouyant that feature in Lise Winer's chapter on Trinidadian creole dictionaries. Vuk's Serb dictionary even includes entries for a substantial number of imaginary herbs!

Given that most folklore surveys rely on established taxonomies and literary hierarchies, it is one of the editor's contentions that dictionaries might throw up examples of folklore which would otherwise be impossible to find, because they do not fit within such classifications. For example, the custom of "Catching the owl" appears in three English dialect dictionaries discussed in Jonathan Roper's chapter, but otherwise goes completely unmentioned in the major compendia of English folklore. "Catching the owl" is a trick or hazing ritual played on new 
recruits on a farm: the new boy is told to stand under the gable end of a barn with a sieve held over his head, while his fellows chase out an owl for him to catch, but instead they throw a bucket of water over him. (The author of this review has both been tricked and played tricks of this kind when he was in the Scouts.) As neither a superstition, nor a calendar custom, nor a recognized folkloric genre, this practice passed unnoticed by folklorists, but its attestation in Devon, the English Midlands and the North-East suggest it was a widespread custom.

Folk naming practices often contain their own etymologies, as well as generating narratives, as Sampson's dictionary demonstrates. The Woods' name for the town of Denbigh was "Bảresapesko Gav", meaning "town of the great snake", thus preserving the popular story of how the town got its Welsh name, when a hero slew the local dragon and called out to the locals "dim bych!", meaning "No more dragon!" (More literally, and prosaically, the name means "little fortress" in Welsh.) However, naming can sometimes reveal more than a story. For example, the Greeks are reputedly "mycophobe", and do not consume mushrooms for culinary, pharmaceutical or other purposes. Yet Maria Vrachionidou, in a paper presented at the SIEF conference on the Historical Dictionary of Modern Greek (but not included in the current collection), reveals that it contains hundreds of local and dialectal names for mushrooms with information about their uses, thus suggesting they held a much more important place in traditional Greek society.

As the authors acknowledge, there are limits to the folkloric utility of dictionaries. Some dictionaries were meant for general circulation and use, and therefore their compilers shied away from erotic or scurrilous material. Vuk Karadžić, partly at Jacob Grimm's urging, did include vulgar and lewd words in the first edition of his dictionary, only to be condemned by the Orthodox Church; he was more circumspect in the second edition. (To take another example, the priest, folklorist and lexicographer Resurrección María de Azkue excluded any word for pederasty from his famous Basque dictionary on the basis that the good Catholic folk of the Basque country would never have encountered the idea, let alone the practice. Georges Lacombe, his colleague in the Basque Academy, felt that Basques might none the less need to refer to the concept, and suggested the neologism "Dodgsonkerria", after the English Bascologist and importuner of young men, Edward Spencer Dodgson). ${ }^{3}$

Other difficulties in the way of using the folkloric content of dictionaries are imposed by the cramped nature of the genre: sources often go unnamed and undated, and even where this information is provided, the material itself can be fragmentary and decontextualized. The result can read a little like Flann O'Brien's humorous I94I additions to Dinneen's entry for Cur in his Irish/English Dictionary, quoted in Diarmuid O Giollain's chapter:

Cur, g. curtha and cuirthe, m. - act of putting, sending, sowing, raining, discussing, burying, vomiting, hammering into the ground, throwing through the air, rejecting, shooting, the setting or clamp in a rick of turf, selling, addressing, the crown of cast-iron buttons which have been made bright by contact with cliff-faces, the stench of congealing badger's

3 Pierre Bidart: La Singularité basque: Généalogie et usages. Paris: Presses Universitaires de France, 200I, p. I95. 
suet, the luminance of glue-lice, a noise made in an empty house by an unauthorised person, a heron's boil, a leprachaun's (sic) denture, a sheep-biscuit, the act of inflating hare's offal with a bicycle pump, a leak in a spirit level, the whinge of a sewage farm windmill, a corncrake's clapper, the scum on the eye of a senile ram, a dustman's dumpling, a beetle's faggot, the act of loading every rift with ore, a dumb man's curse, a blasket, a 'kur', a fiddler's occupational disease, a fairy godmother's father, a hawk's vertigo, the art of predicting past events, a wooden coat, a custard-mincer, a blue-bottle's 'farm', a gravy flask, a timber-mine, a toy craw, a porridge-mill, a fair-day donnybrook with nothing barred, a stoat's stomach-pump, a broken - But what is the use? One could go on and on without reaching anywhere in particular.

Like all successful parodies, this captures something of the authentic tone of the original with its characteristic "devotion to the insignificant". And yet O'Brien, like Dinneen, and for that matter like the Grimm brothers to whom this phrase was first applied (by the art historian Sulpiz Boisserée), understood both the pleasure and the seriousness of "small things", These two principles are also on display throughout this volume. 